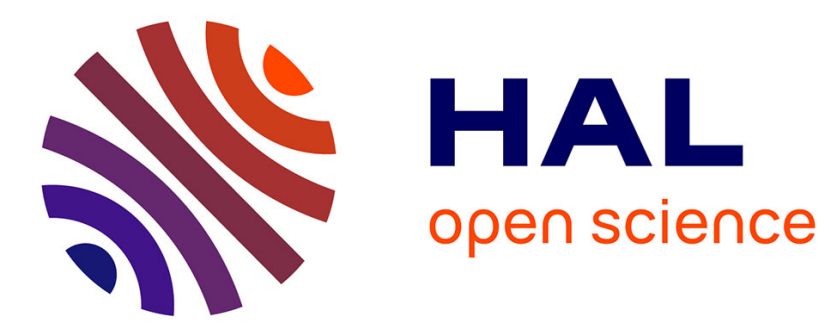

\title{
Non-Remembering' the Holocaust in Hungary and Poland
}

\author{
Andrea Petö
}

\section{To cite this version:}

Andrea Petö. Non-Remembering' the Holocaust in Hungary and Poland. POLIN. STUDIES IN POLISH JEWRY , 2019, pp.471-480. hal-03226342

\section{HAL Id: hal-03226342 \\ https://hal.science/hal-03226342}

Submitted on 22 May 2021

HAL is a multi-disciplinary open access archive for the deposit and dissemination of scientific research documents, whether they are published or not. The documents may come from teaching and research institutions in France or abroad, or from public or private research centers.
L'archive ouverte pluridisciplinaire HAL, est destinée au dépôt et à la diffusion de documents scientifiques de niveau recherche, publiés ou non, émanant des établissements d'enseignement et de recherche français ou étrangers, des laboratoires publics ou privés. 


\section{POLIN}

STUDIES IN POLISH JEWRY

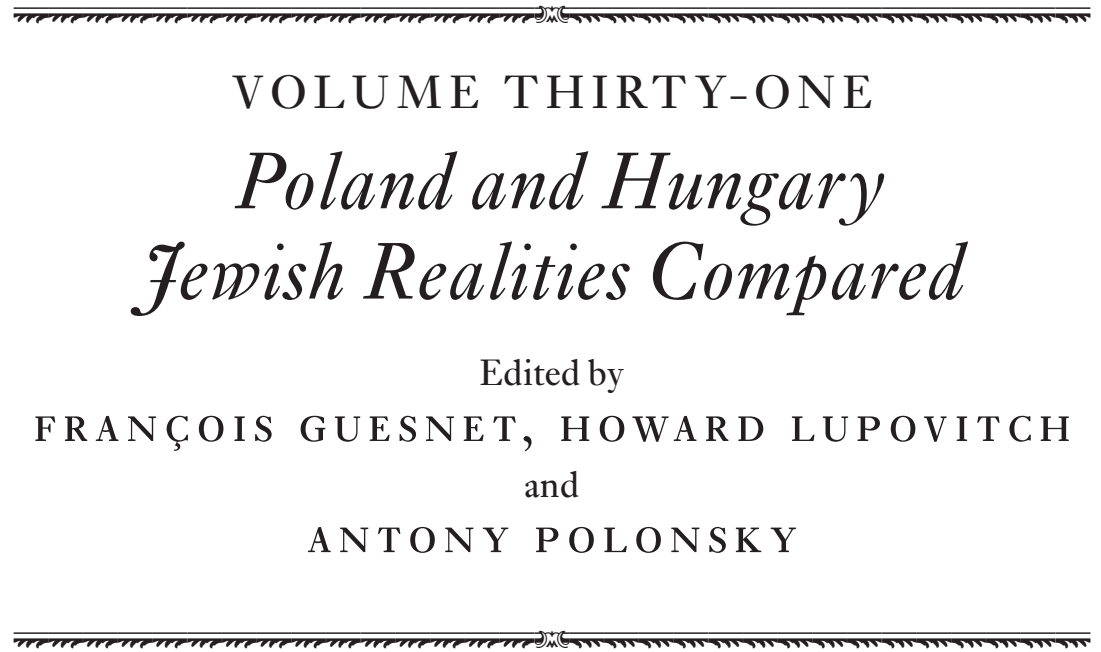

\section{Published for}

The Institute for Polish-Jewish Studies

and

The American Association for Polish-Jewish Studies

\section{O F F P R I N T}

This material is copyright-protected and may not be reproduced in any form, including electronic, without the prior permission in writing of the Littman Library of Jewish Civilization.

Requests to reuse material are processed through PLSclear. Please visit www.plsclear.com to submit your request.

\section{London}

The Littman Library of Jewish Civilization in association with Liverpool University Press 
The Littman Library of femish Civilization

Registered office: 4th floor, 7-IO Chandos Street, London, W I 9DQ

in association with Liverpool University Press

${ }_{4}$ Cambridge Street, Liverpool L69 7ZU, UK

mow.liverpooluniversitypress.co.uk/littman

Managing Editor: Connie Webber

Distributed in North America by

Oxford University Press Inc., I98 Madison Avenue

Nem York, NY ioor6, usA

(C) Institute for Polish-Jemish Studies 2019

All rights reserved.

No part of this publication may be reproduced,

stored in a retrieval system, or transmitted, in any form or by

any means, without the prior permission in mriting of

The Littman Library of Femish Civilization

The paperback edition of this book is sold subject to the condition that it shall not, by may of trade or othermise, be lent, re-sold, hired out or othermise circulated mithout the publisher's prior consent in any

form of binding or cover other than that in which it is published and mithout a similar condition including this condition

being imposed on the subsequent purchaser

Catalogue records for this book are available from

the British Library and the Library of Congress

ISSN 02681056

ISBN 978-I-906764-7I-5 (cloth)

ISBN 978-I-906764-72-2 (pbk)

Publishing co-ordinator: Fanet Moth

Copy-editing: Mark Nemby

Proof-reading: Andrem Kirk and Joyce Rappoport

Index: Bonnie Blackburn

Design, typesetting, and production: Pete Russell, Faringdon, Oxon.

Printed and bound in Great Britain by

Tf International Ltd, Padstom, Cornmall

Articles appearing in this publication are abstracted and indexed in

Historical Abstracts and America: History and Life 


\title{
'Non-Remembering' the Holocaust in Hungary and Poland
}

\author{
ANDREA PETŐ
}

Hungary, as an ally of Nazi Germany, introduced anti-Jewish legislation from I 938 but managed to avoid the deportation of Jews from its post-Trianon territory until the German occupation of the whole country on I9 March I944. The deportation of 430,000 Jews from Hungary was the quickest in the history of the Holocaust, taking less than two months with the active participation of Hungarian civil servants. Miklós Horthy, who governed the country with an iron fist from I9I9, initiated discussions with the Allied forces over a separate armistice, but that did not remain unnoticed by the Germans who installed the fascist Arrow Cross party as a collaborationist government on I 5 October 1944. The final days of Hungary, following the pattern of the Italian Social Republic, had started. ${ }^{1}$ Some parts of Hungary had been liberated by the Soviet Army by December I944, and the provisional government held its first meeting in Debrecen and started to build up the new Hungary.

Liberty Square in the centre of Budapest was renovated in 2014, the seventieth anniversary of the Holocaust in Hungary, and, as a part of the reconstruction, the architect installed a fountain which stops when somebody approaches it and has a fairly large dry space in the middle. It is the joy of young children stuck in the city during the very hot summer days. On 4 October 2014 the performance artist Victoria Mohos placed a chair in the fountain, sat in it, and screamed for fifteen minutes (according to some reports, eighteen), protesting against what is behind the playful and innovative fountain: the monument to the victims of the German occupation. $^{2}$

The Christian-conservative government hoped to use the seventieth anniversary of the Holocaust as a PR blitz to repair its tainted international reputation An earlier version of this chapter was published as A. Peto" , "Hungary 70": Non-Remembering the Holocaust in Hungary', Culture and History Digital Fournal, 3/2 (Dec. 20I4), <http://cultureandhistory.revistas.csic.es/index.php/cultureandhistory/article/view/55/210> (accessed 2 June 2017).

1 R. L. Braham, The Politics of Genocide: The Holocaust in Hungary (New York, I994).

${ }^{2}$ For a time-lapse video of the performance, see A. Boros, 'Viktória I 8 percig üvöltött a német megszállási emlékmű előtt', Cink, 5 Oct. Iо 4 , <http:// cink.hu/viktoria-I 5-percig-uvoltott-a-nemetmegszallasi-emlekmu-I6426I 8837> (accessed 24 Oct. 2014). 
caused by its 'unorthodox policy' on freedom of speech and the role and funding of civil organizations. As part of 'Hungarian Holocaust 70', it allocated a large amount of state funding for the purpose and invited proposals from civil organizations. ${ }^{3}$ So what went wrong? Why did a young performance artist spend fifteen minutes screaming in front of the newly erected monument?

To explain this unarticulated emotional response, I would like to analyse the processes of 'non-remembering'. Non-remembering is a conscious process of forgetting and replacing painful memories with less painful ones. In the 'Hungarian Holocaust 70' commemorations, the non-remembering happened in such a way that it blocked the construction of what Aleida Assmann has called 'dialogic remembering' and promoted further pillarization of the different memory cultures present in Hungary. ${ }^{4}$

The monument to the victims of the German occupation was erected and unveiled during the night in total secrecy and without an official ceremony. It depicts Nazi Germany as an eagle descending upon Hungary represented by the archangel Gabriel and thus expands the category of victim to include Hungary itself. However, Hungary collaborated with Nazi Germany until the last moments of the Second World War, and applying the category of 'victim' in such an undifferentiated way is deeply problematic. Protests against the monument started when the plans for it were first revealed, taking the form of a continuous demonstration on the square, including the exhibition of alternative forms of memory, such as family photographs, photocopied excerpts from books, personal objects, and a Facebook group called 'The Holocaust and My Family'. Demonstrators argued that the monument is revisionist and attempts to undermine the previously anti-fascist consensus that the Hungarian state had a role in the murder of its own citizens.

In this chapter, I argue that the two strategies of non-remembering-substituting one historical narrative with another and resisting remembering the murdered Hungarian citizens in I944-are intertwined. They are both connected to a language problem in Holocaust remembrance. I use three examples to prove my point: a Polish film, a Hungarian teaching exercise, and a local research project.

\section{POKLOSIE}

The Polish film Pokłosie (Aftermath, 20I2), directed by Władysław Pasikowski, discusses — with many allusions to the Old Testament - the guilt of Polish peasants for the murder of the Jewish inhabitants of the village in I939. ${ }^{5}$ The Jews have been erased from the collective memory and from history. The local history books make no mention of them, and their only remains are a number of tombstones, which

${ }^{3}$ Holokauszt 70: Magyar Holokauszt Emlékév, 20I4, 'Civil Alap, 20I4', <http://holokausztem lekev20I4.kormany.hu/civil-alap-20I4 $>$ (accessed 24 Oct. 20I4).

4 A. Assmann, 'History, Memory and the Genre of Testimony', Poetics Today, 27 (2006), 26I-73.

5 A. Pető, 'Memorialisation of the Holocaust', Baltic Worlds, 2-3 (2014), 4-7. 
have been removed from their original location and used to construct a pavement, a fence, and-symbolically - the well of the Catholic parish church. Two brothers from the village seek to discover the secret, despite being warned against it. One never left Poland and runs a small farm, while the other, having emigrated in $198 \mathrm{I}$, returns when he hears about his younger brother's 'odd' behaviour: he has started to move the tombstones from the places they have lain for decades. In doing so, he disturbs the web of concealment and denial. The Jews were murdered because the villagers wanted to acquire their property, although the murders were legitimized by the claim that the Jews had murdered Jesus. The younger brother pays the ultimate price for having revealed the crimes of the villagers: he is crucified on a barn door.

The film is remarkably free of dulling pathos, excessive romanticizing, or superficiality. It demonstrates the possibility of raising, on religious and moral grounds - and risking everything - an issue that has no existence or even a name in the minds of others: those who have lived should be remembered; their tombstones visible; their memory preserved. This is the goal of the younger brother, an uneducated Polish peasant, as, assisted by the local parish priest, he draws attention to the Jewish tombstones. Although the characters in the film have been to school, they have never addressed the history of the Second World War in their local area. For various reasons, modernity (including learning about the Holocaust) has not yet reached the village. Just one language is used to speak about the past and the 'Other': the vulgar language of medieval antisemitism. Symbolically, the Star of David is tied to the gate of the brothers' house, thus branding them 'Others' too.

As they seek to uncover the nameless event, the brothers do not use the language of academic study or of human rights; rather, they seek to formulate an answer to medieval antisemitism at the same conceptual level. By speaking in a visual and moral language that lies outside modernity and secularism, the film is ablefrom the inside - to give a name to the event and to reveal the responsibility of the villagers. It is this interiorized religious and moral sense of responsibility that the film speaks of, using 'post-secular' language. 'Post-secular' was first used by Habermas to describe how the separation of church and state is being questioned within the framework of non-institutional and spiritual religiosity. ${ }^{6}$

In contemporary eastern Europe, after the forcible forgetting under communism, a memory bomb exploded in 1989 . Society was said to have lifted the red carpet under which everything had been hidden, and suddenly everything was rendered visible. In the village in Poktosie, even the red carpet was not really needed: the crimes committed had already been covered up, and, in the absence of any real contact with the outside world, the villagers had been able to use communist laws to bury their secret even deeper. The release of Poktosie gave rise to a heated debate in Poland. There were accusations of anti-Polish slander, and yet the film contained a qualitatively new element: those who had indirectly benefited from the murders

${ }^{6}$ J. Habermas, 'Notes on Post-Secular Society', Nem Perspectives Quarterly, 25/4 (2008), I7-29. 
were the ones who told the story in the film through the uncovering of the Jewish tombstones. The perpetrators and their families are living in houses that once belonged to murdered Jews. Here it is the murderers rather than the victims who are required to narrate the murders. The two brothers search for a language in which to express something that they did not witness themselves but which is, nevertheless, a part of them. This is an example of what Marianne Hirsch has called 'post-memory', but here remembrance does not lead to inclusion in a community of remembrance, and so it differs from the manner in which Holocaust survivors gradually established their own communities. ${ }^{7}$ Rather, here it means being cast out of a community that is founded on a web of silence and complicity and in which there is no possibility of acceptance. The act of being cast out, even to the point of death, goes beyond language and beyond telling. Even so, it is interpreted in a post-secular framework that still manages to be spiritual, for this alone renders it bearable.

The situation in Hungary, home to eastern Europe's largest Jewish survivor community, is even more complicated. While silence and forgetting meant, for many, abandoning their Jewish identity, among some families and groups of friends the discussion of past events was a means of establishing identity. In informal house parties and gatherings, people told family stories, and this became an important means and condition for group cohesion. Personal narration gave credibility to the historical events: by telling the stories, people made them true. Linked with this were efforts to improve the emotional and intellectual well-being of the survivors, thereby combining the command for nihum avelim (comforting the mourners) with memory policy. This command connects the brothers in Poklosie with the two following case studies as battles over the politics of memory in Hungary. In the first I argue that post-secular development has resulted in a qualitative change in storytelling and in the politics of memory and that this change poses a challenge to the Jewish community of survivors as they seek to determine how they should make public their memories and tell their stories to a wider audience. In the second, I show how a Budapest intellectual forcing the local community to confront its past was doomed to fail.

\section{IN THE GLASS CABINET}

This second context is the Vitrin Project of Anthropolis Egyesület, a Hungarian cultural association. ${ }^{8}$ The project uses visual anthropology in primary and secondary school teaching, taking as its point of departure the idea that history should be linked with an object or a specific person, through which emotions can be evoked and experienced. A private initiative, the project began with the processing of the history of a single survivor family, its 'glass cabinet'. Initially, the project received

7 M. Hirsch, Family Frames: Photography, Narrative and Postmemory (Cambridge, Mass., 2002).

${ }^{8}$ See Vitrinmesék, <http://anthropolis.hu/projektek/vitrinmesek> (accessed 24 Oct. 20I4). 
support from the Lindenfeld Company and subsequently from the European Union. In the course of the project, volunteer primary and secondary school teachers of media studies, history, and French were instructed how to tell personal stories using digital storytelling. Participating students themselves selected the stories to be told, did the necessary research, and then made a film. The role of the teacher was to provide the students with assistance throughout this process. The rationale of the project is the reverse of that used for the Shoah Foundation's Visual History Archive, where events were documented on the basis of interviews following an interview guide and resulting in personalized stories of the Holocaust that could then be taught to students. ${ }^{9}$ The films of the Vitrin Project are related only tangentially to the customary historical narratives, for the choice of topic was up to the students. Thanks to students' familiarity with digital technology, its use in the project caused far fewer difficulties than the organizers had anticipated.

At a meeting in Budapest to evaluate the project's findings in March 20I4, a bone of contention among teachers was that ever since it became compulsory in Hungarian schools to hold a Holocaust Memorial Day on i6 April, students had exhibited increasing resistance to instruction on the Holocaust. They expressed the view that Holocaust Memorial Day was just one more formalized and institutionalized expectation in the politics of memory. Some students publicly protested against compulsory viewing of films about the Holocaust. These developments mirrored changes in the Hungarian political discourse that were accompanied by a growing acceptance of verbal antisemitism and a sharper distinction between 'Us' and 'Them'. Secondary school teachers reported that their students were demanding to know why school time was being used to address things of little importance to them and to Hungarians in general. In this way Hungarian-Jewish differences were actually being recreated in connection with an aspect of politics of memory that aimed to end these differences. An enormous challenge for teachers was somehow to smuggle in the little word 'also': that is, to gain acceptance among Hungarian schoolchildren that the Holocaust was 'also' of importance to them. This is a far cry from the story-telling in Poktosie, where the perpetrators felt that they had to speak out and remember and where they do so beyond and outside institutions. This type of discourse is particularly difficult in impoverished regions beset by ethnic conflicts, for instance in north-eastern Hungary, where the 'Them' and 'Us' dichotomy is manifest in the hostility exhibited towards Roma people. One of those involved in the Vitrin Project, a history teacher at a school with mainly Roma students, got an odd opportunity. A far-right paramilitary force from a neighbouring village hounded the local teacher, a village native, out of the area, because she was considered to be Jewish. In the Second World War, her father

9 A. Petô, 'How to Use the Shoah Foundation's Visual History Archive for Teaching at the Graduate Level: A Methodological and Theoretical Reflection', femish Studies at the CEU, 7 (2009-I I), 205I I; see University of Southern California, Shoah Foundation, Visual History Archive, <https://sfi. usc.edu/vha> (accessed 20 Nov. 2017). 
had hidden six Jews at his home, thereby saving them. Instead of receiving recognition from the local community, his daughter was forced to move away from the village. One teacher wanted to include her experiences in the Vitrin Project along with her own Roma students, but a second teacher was too afraid to feature in a film despite guarantees she would remain anonymous. The Hungarian reality differs markedly from the story in Poklosie, although the defining memory cultures survive in eastern Hungary in similar isolation to those in Poland. The vocabulary used by the director of Poktosie was not available at this point in the Vitrin Project, and the teacher declined to make the sacrifice. However, other films are being made within the framework of the project, some of them seeking to give purpose and meaning to the memory of the Holocaust. It is not the experiences and emotions of others that the filmmakers try to put into the films, but their own.

\section{LOCAL HISTORIES THAT MATTER}

The third context is Cserépfalu, which is a small village in north-eastern Hungary with around a thousand inhabitants. Before 1944 nine Jews were living there, who were arrested by the Hungarian gendarmes and taken to the nearby ghetto and never returned. Their property, which was not much, was acquired by the villagers. A young librarian from Budapest, Péter Tóth moved to the village in the I99os, started researching local history, and posted his findings in a blog. ${ }^{10}$ This activity was welcomed by the locals as it attracted tourists to the picturesque village, but when Tóth started to enquire about the Jewish citizens before the deportation of I944, he met with silence and hostility. ${ }^{11}$ On the official web page of the village there is not a word about its traumatic history. The statement that in 200I there were only Hungarians living in the village is a clear message for those considering buying holiday homes that no Roma were living there. ${ }^{12}$

Due to criticism and warnings, Tóth changed the name of Cserépfalu to Cserepflau, but it did not help much. ${ }^{13}$ He organized a remembrance walk to commemorate the deportation of the nine Jewish citizens. Only one other person, who had also recently moved to the village, turned up, and they had to be accompanied by three local policemen. Later, a family of five joined them: they had been threatened with stoning if they participated in the event. The mayor, who in private discussions supported Tóth's work, opted not to participate. Tóth started to gather information about the Jewish inhabitants of the village. He found material in Yad Vashem but not in the local archive. Some Jews had left after a pogrom in I920;

10 P. Tóth, Cserépfalu: Mondogatom szép neved, <http://cserepfalu.tumblr.com> (accessed 24 Oct. 20I4).

11 P. Kovács, “Egyértelmű a hárítás holokausztügyben”: Tóth Péter a cserépfalui zsidódeportálásokról', Magyar Narancs, 25 Oct. 2014, <http://magyarnarancs.hu/kismagyarorszag/egyertelmu-aharitas-holokauszt-ugyben-toth-peter-a-cserepfalui-zsidodeportalasokrol-92268> (accessed 24 Oct. 20I4).

12 Cserépfalu, <http://www.cserepfalu.hu> (accessed 24 Oct. 20I4).

13 Tóth, Cserépfalu. 
however, on I 8 May I 944 nine Jews were living in the village and by I 6 June none. Tóth said in the interview: 'We cannot hide what has happened to them. We cannot live in ignorance, when we know what has happened.'14 The first person plural, however, is problematic, as the community of remembrance is questioned. Who can force a community to remember if they are not willing to do so and it is against their interests?

\section{THE DEMAND TO REMEMBER}

Tikun olam, 'repairing the world', is one of the basic duties of Judaism. Much has been written about how this command is to be interpreted in the various schools of Judaism, but here I want to emphasize the common roots of Christianity and Judaism and the shared expectations that one should seek to make the world a better place. In Hungary, local Jewish organizations bear significant responsibility for their silence on Holocaust remembrance during the communist period and for creating the framework for remembrance after the fall of communism in I989. 'Hungarian Holocaust 70' was an important opportunity to tell the stories, especially since the government offered so much financial support. Instead of a story with a happy ending, a memory war has started. The monument to the victims of German occupation in Liberty Square aimed to create an alternative narrative to the previous anti-fascist discourse. A new Holocaust Museum called the House of Fates is being planned, although no information about the content is available yet. Why is fifteen (or eighteen) minutes of screaming a fitting response to these government actions?

Surprisingly, the framework for story-telling has been determined by the Veritas Historical Research Institute, which was recently established by the Christianconservative government to research the 'truth' ${ }^{15}$ Paradoxically, the civil organizations, historians, and Jewish organizations that have opposed the Veritas Institute have defined their primary task as formulating and sustaining a 'counter-truth'rather than analysing the factors that go beyond the true/false dichotomy.

The Facebook group 'The Holocaust and My Family', membership of which is by invitation only, posts the stories, memories, and reflections of its members. Each one of the stories is heart-breaking and moving. Many people have written the stories of their families and then scanned in or posted photos of their murdered or surviving relatives. A great number have never spoken of these experiences. Each story is full of the pain of people whose voices have never been heard before. One person noted that the establishment of the group was the single positive result of the government's intrusive politics of memory. Members of the group-isolated as they are from the outside world, from hostile commentators, and from 90 per cent of Hungarian society—have continued the politics of memory practices that were

14 Kovács, “"Egyértelmű a hárítás holokausztügyben”'.

${ }_{15}$ See Veritas Történetkutató Intézetet, <www.veritasintezet.hu/en> (accessed 24 Oct. 2014). 
developed in the house parties and gatherings of the I980s. Now, however, they are doing it in the digital space. Here there are no stories that do not fit into the traditional Holocaust narrative: there are no Roma, poor people, or LGBTs. In line with the established narrative, women are mothers and protectors. Why should they remember in any other way, when the accepted framework of remembrance has become what it is over such a long period? While confirmation of one's identity by reference to a group is a basic human need, to move forward it is necessary to think about the extent to which the survivors bear a responsibility. Which command should take precedence: nihhum avelim or tikun olam? In this difficult situation, reversing the logic of victimizer and victim — at first sight a seemingly unacceptable tactic - may lead to meaningful results. The brothers in Poktosie did not have Jewish neighbours, and the villagers had never seen a non-white or non-Catholic Pole. In Poktosie's concluding scene, young people who have arrived from Israel recite Kaddish by the resurrected tombstones. In Hungary, it is as though the inevitable introspection of Jewish memory policy has excluded any possibility of looking outwards, and yet the two practices are not necessarily incompatible.

At its Extraordinary Meeting on 9 February 20 I4, the Federation of Hungarian Jewish Communities declared that it would not take part in the events of 'Hungarian Holocaust 70', because it disagreed with the decisions of the government in the field of the politics of memory. The federation then made it known that it would celebrate the commemorative year separately. Through its decision, the federation effectively renounced the opportunity to participate in the development of a memory culture where many do not understand — and do not even want to understandwhat they are supposed to be commemorating in connection with I944. 'Chosen trauma' (Vamik Volkan's term) is placed in opposition to 'experienced trauma'. ${ }^{16}$ This dilemma, however, is significantly more complicated than that of the Polish brothers in Poktosie, who merely knew about the existence of a secret. The teacher in the northern Hungarian village who shuts herself in her rented room and dares not speak of her father's actions to the second teacher, who wishes to discuss them in the presence of her students, will find her position is far more difficult. The mayor of Cserépfalu posts the advertisement for the remembrance walk for the nine murdered Jewish citizens of his village, but he himself does not participate as he knows nobody else from the village will do so.

The crimes are still present; they have not passed away and will not pass away. The only change concerns the framework of remembering. But if we are to make the world a better place by speaking about such issues, then we also need to recognize that the world has changed: digital technology has not only modified our access to the past, it has also altered what we regard as authentic. A further change revolves around our emotional political expectations in a post-secular world. What remains, however, is tikun olam as a practical everyday command. By recognizing

${ }^{16}$ V. D. Volkan, 'Transgenerational Transmissions and Chosen Traumas: An Aspect of LargeGroup Identity', Group Analysis, 34/ I (2001), 79-97. 
emotions and identity, we are able to reach out to others. If we fail to understand Others-Roma or LGBTs - we too will be left vulnerable. And unless we can define ourselves in conjunction with someone else, we will have failed to truly understand the deeply immoral and corrupt logic that gives rise to the notion of the 'Other'. We all bear a responsibility for the rise in antisemitism, for Holocaust denial, and for the relativizing of crimes. Sulky disdain for those who think differently from 'Us' and a belief that 'We' are the only ones who know objectively what happened will lead only to a further polarization of society and of memory cultures. When the librarian from Budapest demands that 'We' should remember and one more person shows up, the failure of this strategy is demonstrated.

In the recent past in Hungary, there has been a failure to develop an internalized narrative among those who do not regard - or do not experience- the Holocaust as their own personal story of suffering and who, within the framework of postmemory, do not consider themselves in any manner responsible. Yet the parents and grandparents of these people worked very diligently in the Hungarian state administration to make inventories of the assets of the Jews, even moving into the apartments and houses allocated to them after the Jews' departure and always considering it best not to enquire about their previous owners. In the impoverished village in northern Hungary, the Roma children asked the teacher in vain about her father's stories: they received no answer. The intellectual who moved from Budapest to a small village in the northern part of Hungary was asking questions that the villagers are not ready to answer, and they met the silence of Poktosie.

\section{CONCLUSION}

The history of the Holocaust is the history of Europe. As Europeans we all continue to live it. It is not wise to appropriate to ourselves the story of suffering, because even in the short term such a course will lead to isolation, pillarization, and a rise in antisemitism. The brothers in Poktosie, by going beyond themselves and the traditions of their family and community, could reach out for a different post-secular memory politics. That was put in into practice by the 'Matzeva Project' in 20I4, which collected more than I,00o tombstones (matsevot) from the Praga district of Warsaw, which had been built into roads, walls, even toilets, or used as knife sharpeners, and returned the fragments to the cemetery. ${ }^{17}$ The two brothers in Poktosie render themselves vulnerable as a result of similar actions, but this task must be faced. By following the traditional command of tikun olam, we can accomplish the task - doing so hopefully with less bloodshed than in the film, although we should not be under any illusions.

The main argument against the memory politics of the Hungarian government is that with the monument to the victims of the German occupation it revised the history of the Holocaust in Hungary. Aviezer Tucker identifies three types of

17 Matzeva Project, <http://matzeva.org > (accessed 20 Nov. 20I7). 
historical revision. The first is significance-driven revision: that is, when there is a change in what historians find significant in history. The second is evidence-driven revision: when new evidence is discovered. And the third is value-driven revision: when historical events and processes are re-evaluated due to a new system of values becoming hegemonic. ${ }^{18}$ In the case of the two villages in the northern part of Hungary significance-driven revision is going in parallel with value-driven revision: what happened in those villages in 1944 is not considered to be important by the local villagers. The government-supported memorialization projects are constructing the monuments for the murdered Jews as if these murders happened in a social and cultural vacuum. If these tendencies of revisionism are supported by these two strategies of non-remembering, then there is nothing left to do but to scream.

18 A. Tucker, 'Historiographic Revision and Revisionism: The Evidential Difference', in M. Kopeček (ed.), Past in the Making: Historical Revisionism in Central Europe after 1989 (Budapest, 2008), 3 . 